\title{
Ovariectomy improves lactation persistency in dairy cows
}

\author{
L. Yart, ${ }^{\star} \dagger$ F. Dessauge,${ }^{*} \dagger$ L. Finot, ${ }^{\star} \dagger$ S. Barbey,‡ P. G. Marnet, ${ }^{\star} \dagger$ and V. Lollivier ${ }^{\star}{ }^{1}$ \\ *INRA UMR 1348 Physiologie, Environnement et Génétique pour l'Animal et les Systèmes d'Elevage, F-35000 Rennes, France \\ †Agrocampus UMR 1348 Physiologie, Environnement et Génétique pour l'Animal et les Systèmes d'Elevage, F-35000 Rennes, France \\ †INRA UE 326 Le Pin-au-Haras, F-61310 Exmes, France
}

\begin{abstract}
A current trend in the dairy industry is to reduce milk yield at the peak of lactation and improve lactation persistency. Lactation persistency is influenced by livestock management factors, such as feeding level or milking frequency, or by physiological status, including reproductive status or calving period. These factors modulate mammary gland apoptosis and tissue remodeling, which determine the rate of decline of milk yield after the lactation peak. Previous studies on lactating cows suggested that ovarian steroids have a negative effect on milk yield after the peak of lactation. In the present study, 4 Holstein $\times$ Normande crossbred multiparous cows were ovariectomized at the time of the lactation peak, and 5 cows underwent sham operations. All of the cows were maintained in lactation for 14 mo and milk yield was recorded daily. At slaughter, mammary epithelial cell apoptosis and mammary tissue remodeling were assessed. Ovariectomized cows had improved lactation persistency and presented an average daily milk gain of $2.5 \mathrm{~kg}$ compared with the sham-operated cows between mo 6 and 14 of lactation. The ovariectomy appears to have limited the decline in the milk yield after the peak of lactation by reducing mammary epithelial cell apoptosis [by reducing poly(adenosine diphosphate-ribose) polymerase expression] and mammary-tissue remodeling (by reducing matrix metalloproteinase activity). In conclusion, removal of ovarian secretion via ovariectomy improved the cows' lactation persistency.
\end{abstract}

Key words: dairy cow, lactation persistency, ovariectomy, mammary gland

\section{INTRODUCTION}

The mammary gland is a dynamic organ that undergoes cyclic developmental and regressive changes during the lifetime of a female mammal. Mammogenesis

Received November 25, 2011.

Accepted February 27, 2012.

${ }^{1}$ Corresponding author: Vanessa.Lollivier@agrocampus-ouest.fr begins during embryonic life with development of the first mammary gland rudiments and ductal system. After birth, during the prepubertal period, the ductal growth of the mammary parenchyma occurs through the fat pad. During puberty, with the onset of ovarian cyclicity, the ruminant mammary parenchyma develops in a compact, highly arborescent, parenchymal mass surrounded by a dense, connective matrix (Akers et al., 1990). Ductal elongation and lobuloalveolar development are accomplished during growth and pregnancy to prepare for future milk production. At the end of lactation, the mammary gland undergoes involution, which corresponds to regression of the secretory tissue, a reduction in alveolar size, and a loss of mammary epithelial cells (MEC). Ovarian steroids (estradiol and progesterone) appear to be key regulators of the different stages of mammogenesis and mammary function. Mammogenesis in early life is a determinant for the subsequent enhancement of lactation. Numerous studies have demonstrated that the ovaries play a critical role in regulating mammary development in the early lives of goats (Dessauge et al., 2009) and heifers (Purup et al., 1995; Berry et al., 2003; Akers et al., 2005). Wallace (1953) was the first to suggest that ovarian secretion is crucial for pubertal mammogenesis and reported a strong developmental alteration of the mammary parenchyma in ovariectomized heifers. Later in the life of dairy ruminants, ovarian steroids play an active role in the completion of mammogenesis during pregnancy. In nonpregnant and nonlactating cows, Turner et al. (1956) stimulated MEC differentiation and lobuloalveolar development and initiated milk production by estrogen and progesterone treatment. These researchers obtained mammary secretions with a colostral appearance, which subsequently changed to milk that appeared normal (Turner et al., 1956). However, little is known about the effects of ovarian secretion on the mammary gland and milk production after the peak of lactation. Sex steroids, such as estrogen and progesterone, seem to affect milk yield (MY) negatively during lactation. The administration of exogenous estradiol in mid lactation cows, with or without progesterone, induced a rapid decrease in MY (Mollett et al., 1976; Athie et al., 1996; Delbecchi et al., 2005). Delbecchi et 
al. (2005) reported that MY was decreased by 15 and $82 \%$ at 3 and $11 \mathrm{~d}$, respectively, after the first injection of a supraphysiological dose of estradiol.

Lactation persistency is characterized by the rate of decline in the MY after the peak of lactation. In the udder, milk secretion and therefore lactation persistency depend on the number and activity of MEC (Boutinaud et al., 2004). Thus, the decline in MY after the peak of lactation would result from a loss of cells through apoptosis that occurs mainly in the parenchymal tissue (Stefanon et al., 2002). The apoptosis rate in the mammary gland increases during the course of lactation and is followed by an increase in mammary tissue remodeling, which results in alveolar size regression during involution (Stefanon et al., 2002). The intensive remodeling that occurs in the mammary gland during development, function, and involution requires degradation of the extracellular matrix by matrix metalloproteinases (MMP; Rabot et al., 2007). Moreover, in vitro experiments conducted on murine MEC showed that extracellular matrix integrity is required to prevent MEC apoptosis and suggested that interactions between the cells and the extracellular matrix could act in vivo to control the cell death that occurs during mammary gland involution (Pullan et al., 1996). Several pathways are involved in mammary cell apoptosis during involution. Poly(ADP-ribose) polymerase (PARP) intervenes in DNA fragmentation during one of the final stages of cell death (Boulares et al., 1999). In the mouse mammary gland, PARP protein levels are maximal on d 4 of involution (Guenette et al., 1994), when the number of mammary cells in the final stage of apoptosis is maximal. Thus, lactation persistency could be modulated through factors that influence MEC apoptosis and mammary tissue remodeling (Stefanon et al., 2002).

The current trend in dairy systems is to improve lactation persistency and extend lactation, rather than increase MY at the peak of lactation. To improve lactation persistency and extend lactation would reduce calving frequency and, consequently, limit the risks linked to parturition and stabilize the herd annual milk production. Lactation persistency is considered to be steady from the second lactation (Schutz et al., 1990), but it could be modulated by other livestock management factors, such as the calving period, pregnancy, feeding level, or frequency of milking (Capuco et al., 2003).

In dairy cattle, it has been reported that removal of the ovaries by ovariectomy improves lactation persistency (du Roizel-Marlier, 2004). However, the effects of ovariectomy on lactation persistency and the mammary glands remain unclear. In this study, we used ovariec- tomized lactating cows as an experimental model to test the hypotheses that (1) ovariectomy of dairy cows improves lactation persistency, and (2) the presumptive improvements in persistency would be linked to changes occurring in mammary gland.

\section{MATERIALS AND METHODS}

All of the animal procedures were approved by the French Ministry of Agriculture's animal ethics committee in compliance with French regulations (Decree No. 2001-464, May 29, 2001).

\section{Animals and Experimental Design}

Nine Holstein $\times$ Normande crossbred multiparous cows (lactation rank 2 and 3) that were calving between January 28 and March 10, 2010, were used in this study. Cows were housed at the experimental farm of the INRA Le Pin-au-Haras (France). During the entire experimental period, cows were collectively housed in barns during the winter and in fields during the summer, individually fed with an automatic concentrate feeder, and milked twice daily. The cows were divided into 2 equivalent groups based on parity, calving date, and previous lactation performances (total MY on d 280 of lactation and persistency). One group was ovariectomized ( Ovx, $\mathrm{n}=4$, MY at $280 \mathrm{~d}=5,688.2 \mathrm{~kg} \pm 462.9)$ approximately $60 \mathrm{~d}$ postpartum $( \pm 13 \mathrm{~d})$, whereas the other group received a sham operation $(\mathrm{n}=5$, MY at $280 \mathrm{~d}=6,373.9 \mathrm{~kg} \pm 446.9)$. Fifteen days before the surgery, all of the cows were subjected to a mammary gland biopsy. The Ovx cows were ovariectomized using the Chappat method (Chappat, 1993). Briefly, the cows were sedated with xylazine $\mathrm{HCl}$ (10 mg, i.v.; Rompun, Bayer HealthCare AG, Leverkusen, Germany) and butorphanol tartrate $(5 \mathrm{mg}$, i.v.; Torbugesic, Fort Dodge Animal Health, Fort Dodge, IA). After cleansing, the vaginal wall and the peritoneum were sectioned on the dorsal side, close to the cervix, using Krebs scissors. Ovarian pedicles were then bound with a "screw nutelastic" system, which was mounted on a pipe. The sham-operated cows received sedation with xylazinebutorphanol and were subjected to vaginal wall and peritoneum sectioning. The ovarian pedicles were not bound, but the presence of the ovaries was verified by an intraabdominal palpation. All of the cows were maintained in lactation and nonpregnancy for 14 mo and were weighed regularly. The sham-operated cows did not receive any treatment for estrus synchronization during the study.

After 14 mo of lactation, the cows were slaughtered at the Socopa slaughterhouse (Gacé, France). At slaugh- 
ter, the uterus and udders (with teats, skin, and lymph nodes) were removed and weighed before processing.

\section{Milk Production and Persistency Calculation}

Milk yield was recorded daily during the 14 mo. The milk composition and SCC were determined $1 \mathrm{~d}$ per week in mo 14 of lactation. The milk protein, fat, and lactose contents were determined by an independent laboratory using an infrared method (Lilano, Saint-Lô, France).

The lactation persistency was calculated according to Sölkner and Fuchs (1987):

$$
\mathrm{P}_{x-y}=\frac{\text { Mean of MY from d } x \text { to d } y}{\text { Mean of MY from d } 0 \text { to d } 100} \times 100 .
$$

In this study, persistency was expressed as a percentage of the MY relative to the first $100 \mathrm{~d}$ of lactation (reference period) and was calculated for 4 periods of interest: from d 100 to 200, from d 200 to 300, from d 300 to 400, and from d 100 to 400 .

\section{Blood Sampling and Progesterone Assay}

Blood samples were obtained from the tail vein $15 \mathrm{~d}$ before surgery and $1 \mathrm{~d}$ before slaughter to determine the plasma progesterone concentration. Sampling was performed using Monovette syringes coated with sodium heparin (Sarstedt, Nümbrecht, Germany). The plasma was immediately separated by centrifugation at $3,000 \times g$ for $15 \mathrm{~min}$ at $4^{\circ} \mathrm{C}$ and was stored at $-20^{\circ} \mathrm{C}$ until assay. Plasma progesterone concentrations were measured with the AIA 360 robot (Kitvia, LabartheInard, France). The intra- and interassay CV were 12.3 and $7.5 \%$, respectively.

\section{Tissue and Milk Sampling}

Mammary tissue samples were collected $15 \mathrm{~d}$ before surgery by biopsy (method adapted from Farr et al., 1996) and at slaughter. The mammary tissue samples were always obtained from the left rear quarter in an area located approximately halfway between the base of the teat and the dorsal body wall, corresponding to the alveolar region. For each animal, several tissue samples were directly frozen in liquid nitrogen and stored at $-80^{\circ} \mathrm{C}$ until protein extraction. Other mammary tissue samples were washed in PBS before fixation for histological analysis. Milk samples were collected the day before slaughter during the morning milking for zymography. The samples were stored at $-20^{\circ} \mathrm{C}$ until analysis.

\section{Histological Analysis}

The mammary tissue samples used for histological analysis were fixed in $4 \%$ paraformaldehyde ( $\mathrm{pH}$ 7.4) for $2 \mathrm{~h}$ and embedded in paraffin using standard protocols. Tissue sections (5 $\mu \mathrm{m}$ thickness) mounted on SuperFrost Plus slides (Labo-Moderne, Paris, France) were deparaffinized in 3 changes of xylene and rehydrated in a graded ethanol-water bath series. After rehydration, the tissue sections were stained with hematoxylin and eosin. Two tissue sections per animal were analyzed, and the areas of the parenchyma and lumen were measured using the Mercator software package (Explora Nova, La Rochelle, France).

\section{Gelatin Zymography}

Gelatin zymography was used to quantify MMP2 activity in the milk. Whole milk samples were centrifuged at 2,000 $\times g$ for $30 \mathrm{~min}$ at $4^{\circ} \mathrm{C}$. The supernatants containing the fat were removed to obtain skim milk. The protein concentrations were determined using a bicinchoninic acid (BCA) protein assay kit (Thermo Fisher Scientific, Brebières, France), before dilution in a zymogram sample buffer (Bio-Rad Laboratories, Marnes-la-Coquette, France). Proteins (5 $\mu \mathrm{g}$ per lane) underwent electrophoresis on 10\% SDS-PAGE gels that were co-polymerized with $1 \mathrm{mg} / \mathrm{mL}$ of gelatin (Sigma Aldrich Chimie, Lyon, France).

The gels were scanned by transillumination with an ImageQuant LAS 4000 imager (GE Healthcare BioSciences AB, Uppsala, Sweden). The MMP2 (57 kDa) activity was measured by quantifying the integrated optical density of the clearly visible bands using the ImageQuant Tool Lab software (GE Healthcare BioSciences AB).

\section{Western Blot Analysis}

Frozen mammary tissue samples were ground in liquid nitrogen with the A11 IKA analytical grinding mill (VWR, Fontenay-sous-Bois, France) to obtain a homogenate. Total proteins were extracted from the powder using a tissue protein extraction reagent ( $\mathrm{T}$ PER, Thermo Fisher Scientific). After homogenization, the samples were centrifuged at $10,000 \times g$ for 5 min at $4^{\circ} \mathrm{C}$, and the supernatant containing the total proteins was recovered. The protein concentrations were determined using a BCA protein assay kit (Thermo Fisher Scientific). The lysates were subsequently mixed with sample buffer (50 mM Tris-HCl pH 6.8, 2\% SDS, 0.1\% bromophenol blue, $20 \%$ glycerol, and $0.1 M$ dithiothreitol) and boiled for $5 \mathrm{~min}$ at $95^{\circ} \mathrm{C}$ for protein separation using SDS-PAGE electrophoresis. 
Proteins $(30 \mu \mathrm{g}$ per lane) were separated on $10 \%$ SDS-polyacrylamide gels, transferred to polyvinylidene difluoride membranes (GE Healthcare Bio-Sciences $\mathrm{AB}$ ) and incubated with blocking solution [5\% dry skim milk dissolved in Tris-buffered saline with Tween (TBS-T) buffer, $50 \mathrm{mM}$ Tris-HCl, pH 8.6, $150 \mathrm{mM}$ $\mathrm{NaCl}$, and $0.1 \%$ Tween] for $30 \mathrm{~min}$. The membranes were incubated overnight at $4^{\circ} \mathrm{C}$ with mouse monoclonal anti-actin (1:5,000, A5441, Sigma Aldrich Chimie) and rabbit polyclonal anti-PARP (1:1,000, \#9532, Cell Signaling Technology Inc., Danvers, MA). Next, the membranes were washed with TBS-T and incubated with horseradish peroxidase-conjugated anti-mouse or antirabbit secondary antibodies (31450 and 31464, Thermo Fisher Scientific) applied at a 1:500 dilution for $1 \mathrm{~h}$ at room temperature $\left(20^{\circ} \mathrm{C}\right)$. After washing with TBS$\mathrm{T}$, the membranes were incubated in ECL substrate (GE Healthcare Bio-Sciences AB) for 1 min. Membrane imaging was performed by chemiluminescence with an ImageQuant LAS 4000 imager (GE Healthcare BioSciences AB). The integrated optical densities of the bands were quantified using the ImageQuant Tool Lab software (GE Healthcare Bio-Sciences AB). Each sample was normalized based on the actin content.

\section{Statistical Analysis}

Data are expressed as means \pm standard errors of the means. A Student's $t$-test was used to compare the mean values resulting from both treatments (sham-operated and Ovx) using the R software (freeware version 2.12.2; http://www.r-project.org/). Milk production values were analyzed with repeated-measures ANOVA (Gee pack function in $\mathrm{R}$ freeware, Hojsgaard et al., 2006). The effects were considered significant at $P<0.05$ and to tend to be significant for $0.05<P<0.1$.

\section{RESULTS}

\section{Validation of the Ovariectomy Model}

To validate our surgical approach for the suppression of ovarian secretion, plasma progesterone assays were performed before ovariectomy (at 2 mo of lactation) and at slaughter (at 14 mo of lactation). Plasma progesterone concentrations were similar between the sham-operated and Ovx cows before ovariectomy, but the Ovx cows presented a severe decrease in the plasma progesterone concentrations at slaughter (in mo 14 of lactation; Figure 1A, $P<0.01$ ), and the sham-operated cows presented estrus behavior during the study (data not shown). In addition, the uterine weights at slaughter were significantly lower in the Ovx cows $(240 \mathrm{~g} \pm$ 19) than in the sham-operated cows (514 $\mathrm{g} \pm 45$; Figure $1 \mathrm{~B}, P<0.01$ ). The uterine photographs (Figure $1 \mathrm{C}$ ) also illustrate the difference in the uterus size at slaughter, between Ovx and sham-operated cows.

\section{Ovariectomy Improved Lactation Persistency and Milk Yield}

The daily MY was recorded for the sham-operated and Ovx cows from calving to slaughter, and lactation persistency was calculated for 4 periods according to the method described by Sölkner and Fuchs (1987). As shown in Table 1, ovariectomy significantly improved lactation persistency in both the third and fourth quarters of lactation (by 6.4 points from d 200 to 300 and by 9.5 points from d 300 to $400 ; P=0.04$ ). Ovariectomy also improved lactation persistency by 6.6 points when the entire lactation period was considered (d 100 to 400; $P=0.01$ ).

In mo 14 of lactation, MY increased by 36\% (Table 2 ) in the Ovx cows and was significantly higher between mo 6 of lactation (4 mo after the ovariectomy) and mo 14 of lactation (Figure 2) compared with that in the sham-operated cows. This increase corresponded to an average daily milk gain of $2.5 \mathrm{~kg}$ from mo 6 to 14 of lactation for the Ovx cows.

\section{Ovariectomy Did Not Affect Milk Composition}

Ovariectomy tended to increase somatic cell release in milk when measured in mo 14 of lactation $(P<0.1)$. Ovariectomy significantly increased the daily fat, protein, and lactose yields $(P<0.05)$; however, it did not affect milk composition (i.e., fat, protein, and lactose contents; Table 2).

\section{Ovariectomy Did Not Affect Global Mammary Gland Organization}

The gross udder weights at slaughter for shamoperated and Ovx cows were not significantly different (Table 2). Moreover, histological observations of the entire mammary tissue sections showed classical mammary epithelial structures, which suggested that the lactating cows in both the sham-operated and Ovx groups had well-developed secretory tissue, thin epithelium, and large lumen area and ducts (Figure $3 \mathrm{~A}$ and B). Quantitative image analysis revealed no statistical difference in total mammary parenchyma area or total lumen area (Figure 3C).

\section{Ovariectomy Limited Mammary Gland Remodeling and MEC Apoptosis}

Mammary gland remodeling was assessed at slaughter by measuring MMP2 gelatinase activity in milk. 

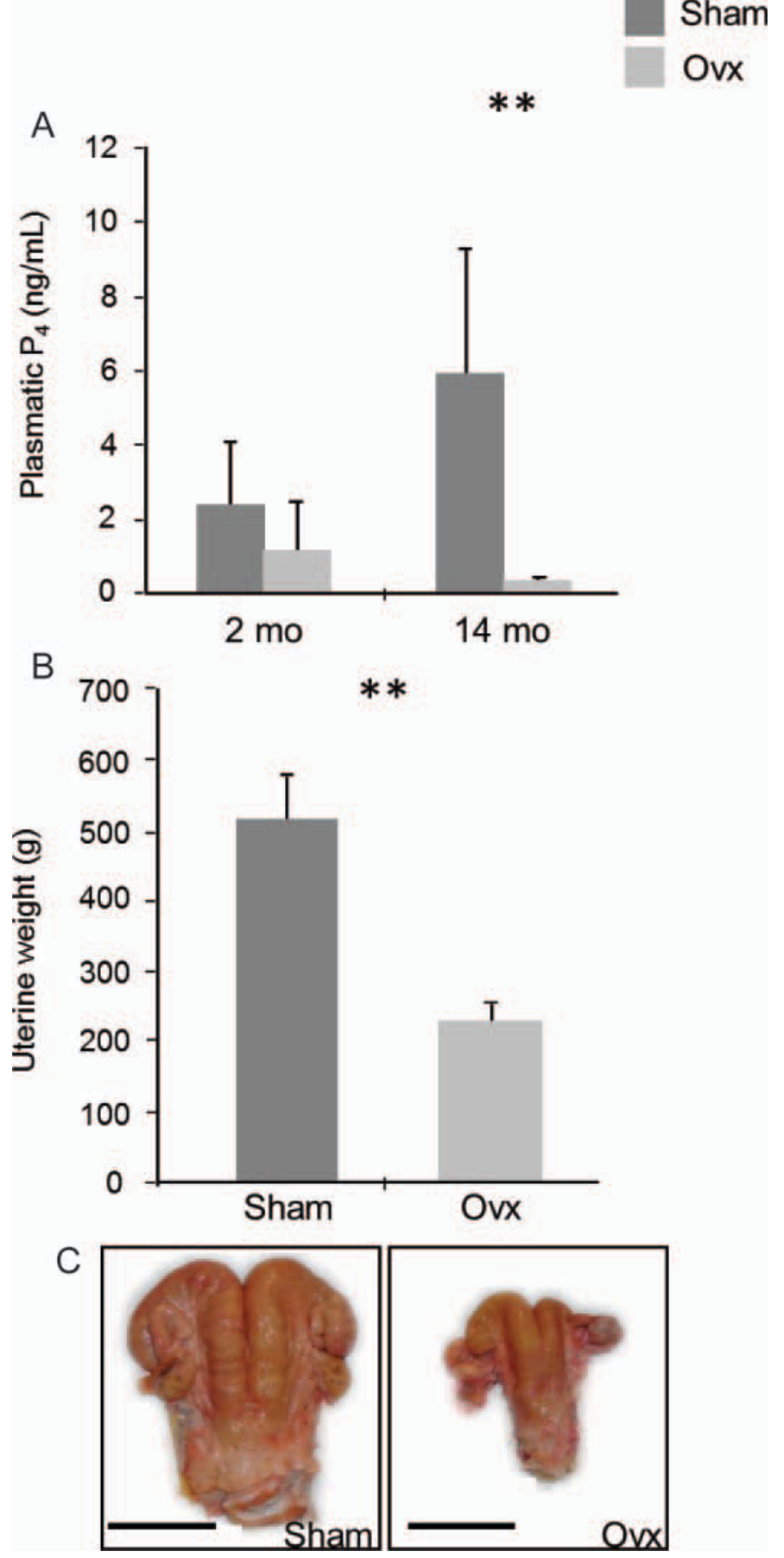

Figure 1. Effect of the ovariectomy on plasmatic progesterone concentration and uterine weight. Multiparous nonpregnant cows were either ovariectomized (Ovx, $\mathrm{n}=4)$ or sham-operated (sham, $\mathrm{n}=5$ ) at 2 mo of lactation and slaughtered after 14 mo of lactation. (A) Plasma progesterone concentrations were measured at 2 mo of lactation (before surgery) and at 14 mo of lactation (the day before slaughter). Note the significant decrease in the progesterone concentration in the Ovx cows in mo 14 of lactation $\left({ }^{* *} P<0.01\right)$. (B) and (C) At slaughter, the uteri were dissected and weighed. Note that the uterine weights were significantly lower in the Ovx cows $\left(\mathrm{B}{ }^{* *} P<0.01\right)$. Bars represent $10 \mathrm{~cm}(\mathrm{C})$. The progesterone concentrations and uterus weights are expressed as means \pm SEM. Color version available in the online PDF.
The active form of MMP2 (57 kDa) was detected using a zymography gel (Figure 4). A quantitative analysis by pixel intensity measurement showed that total MMP2 activity at slaughter tended to be lower in the Ovx cows $(P<0.1)$. Expression of PARP was used as an indicator of apoptosis in the mammary gland. Western blot quantification of the PARP protein concentration showed that the relative abundance of PARP protein in the mammary tissue at slaughter was significantly decreased by ovariectomy (Figure 5; $P<0.05$ ).

\section{DISCUSSION}

Lactation persistency is highly dependent on parity: primiparous cows usually present a lower MY than multiparous cows in the early stage of lactation but they have higher persistency (Miller et al., 2006). However, lactation persistency decreases between first and second lactation and is considered to be subsequently steady (Schutz et al., 1990). Livestock management factors, such as milking frequency, feeding, and calving period, are known to modulate lactation persistency (Capuco et al., 2003). In our study, we demonstrated that ovariectomy of dairy cows around mo 2 of lactation improved lactation persistency, and ovariectomized cows presented an average daily milk gain of $2.5 \mathrm{~kg}$ from mo 6 to 14 of lactation. In France, dairy cows were widely ovariectomized between 1850 and 1940 by breeders and veterinarians to improve meat quality and milk production. The technique underwent resurgence in the late 1980s, when the European Union banned the use of hormones to produce milk or meat, but its extent of use is currently unknown. A retrospective farm survey of Holstein and Montbéliarde cows demonstrated that ovariectomy of lactating cows at $125 \mathrm{~d}$ of lactation extended the duration of the lactation compared with pregnant cows, with an average gain of $2.8 \mathrm{~kg}$ in daily milk production for the ovariectomized cows being observed during the entire lactation (du RoizelMarlier, 2004). Ovariectomy was therefore concluded to improve total MY and lactation persistency compared with pregnant cows while avoiding the dry period and extended lactation. However, in that study, the cows were ovariectomized on farm without a fixed method or time of ovariectomy.

In our study, we observed that MY was significantly higher in ovariectomized cows after mo 6 of lactation, which corresponds to 4 mo after the ovariectomy; this difference in MY increased over time. Similarly, persistency calculations for the different stages of lactation showed that lactation persistency was improved in ovariectomized cows in the mid and late periods of lactation. Thus, ovariectomy improved lactation persistency by limiting the decrease in MY after the peak of 
Table 1. The effect of ovariectomy (Ovx) on lactation persistency, expressed as means \pm SEM of the percentage of the average milk yield during the period of interest relative to the average milk yield during the reference period (from d 0 to 100)

\begin{tabular}{lccc}
\hline & \multicolumn{2}{c}{ Treatment } & \\
\cline { 2 - 3 } & $\begin{array}{c}\text { Sham } \\
\text { Period }\end{array}$ & $\begin{array}{c}\text { Ovx } \\
(\mathrm{n}=4)\end{array}$ & $P$-value \\
\hline d 100 to 200 & $70.5 \pm 1.5$ & $75.2 \pm 2.0$ & 0.1 \\
d 200 to 300 & $51.8 \pm 1.6$ & $58.2 \pm 2.2$ & 0.04 \\
d 300 to 400 & $35.0 \pm 2.6$ & $44.5 \pm 3.6$ & 0.04 \\
d 100 to 400 & $53.0 \pm 0.8$ & $59.6 \pm 2.4$ & 0.01 \\
\hline
\end{tabular}

lactation without modifying the fat, protein, or lactose concentrations in the milk. In nonpregnant cows, the ovaries are known to be the main source of estrogen and progesterone. In this study, through an ovariectomy, we suppressed the cyclic secretion of estrogen and progesterone, which was confirmed by the low levels of plasma progesterone and low uterus weights at slaughter in ovariectomized cows (Johnson et al., 1997; Berry et al., 2003). Previous studies indicated that these 2 steroid hormones negatively affect lactation persistency (Mollett et al., 1976; Athie et al., 1996; Delbecchi et al., 2005). During pregnancy, estrogen and progesterone are widely produced by the fetoplacental unit. In pregnant
Table 2. The effect of ovariectomy (Ovx) on the milk yield and milk composition (means \pm SEM) in mo 14 of lactation and on udder weight (with teats, skin, and lymph nodes) at slaughter

\begin{tabular}{|c|c|c|c|}
\hline \multirow[b]{2}{*}{ Variable } & \multicolumn{2}{|c|}{ Treatment } & \multirow[b]{2}{*}{$P$-value } \\
\hline & $\begin{array}{l}\text { Sham } \\
(\mathrm{n}=5)\end{array}$ & $\begin{array}{c}\text { Ovx } \\
(\mathrm{n}=4)\end{array}$ & \\
\hline Milk yield $(\mathrm{kg} / \mathrm{d})$ & $10.2 \pm 1.3$ & $13.9 \pm 1.1$ & 0.01 \\
\hline \multicolumn{4}{|l|}{ Fat } \\
\hline Yield $^{1}(\mathrm{~g} / \mathrm{d})$ & $449 \pm 82$ & $708 \pm 44$ & 0.03 \\
\hline Content $^{1}(\mathrm{~g} / \mathrm{kg})$ & $43.5 \pm 3.2$ & $51.5 \pm 3.2$ & 0.15 \\
\hline \multicolumn{4}{|l|}{ Protein } \\
\hline Yield $^{1}$ (g/d) & $376 \pm 56$ & $537 \pm 34$ & 0.05 \\
\hline Content $^{1}(\mathrm{~g} / \mathrm{kg})$ & $36.7 \pm 0.8$ & $38.8 \pm 1.3$ & 0.2 \\
\hline \multicolumn{4}{|l|}{ Lactose } \\
\hline Yield $^{1}(\mathrm{~g} / \mathrm{d})$ & $420 \pm 54$ & $578 \pm 37$ & 0.05 \\
\hline Content $^{1}(\mathrm{~g} / \mathrm{kg})$ & $41.2 \pm 0.8$ & $41.6 \pm 0.7$ & 0.8 \\
\hline $\operatorname{SCC}\left(10^{3} / \mathrm{mL}\right)$ & $290 \pm 38$ & $436 \pm 61$ & 0.08 \\
\hline Udder weight $(\mathrm{kg})$ & $21.7 \pm 1.6$ & $21.4 \pm 1.3$ & 0.1 \\
\hline
\end{tabular}

${ }^{1}$ Average values in mo 14 of lactation.

cows, estrogen secretion by the fetoplacental unit starts at approximately d 100 of pregnancy and progressively increases until parturition (Patel et al., 1999). Several studies reported a negative effect of a concomitant pregnancy on MY (Bachman et al., 1988; Bertilsson et al., 1997; Norgaard et al., 2008) and suggest that delaying the time of insemination would delay the exposure

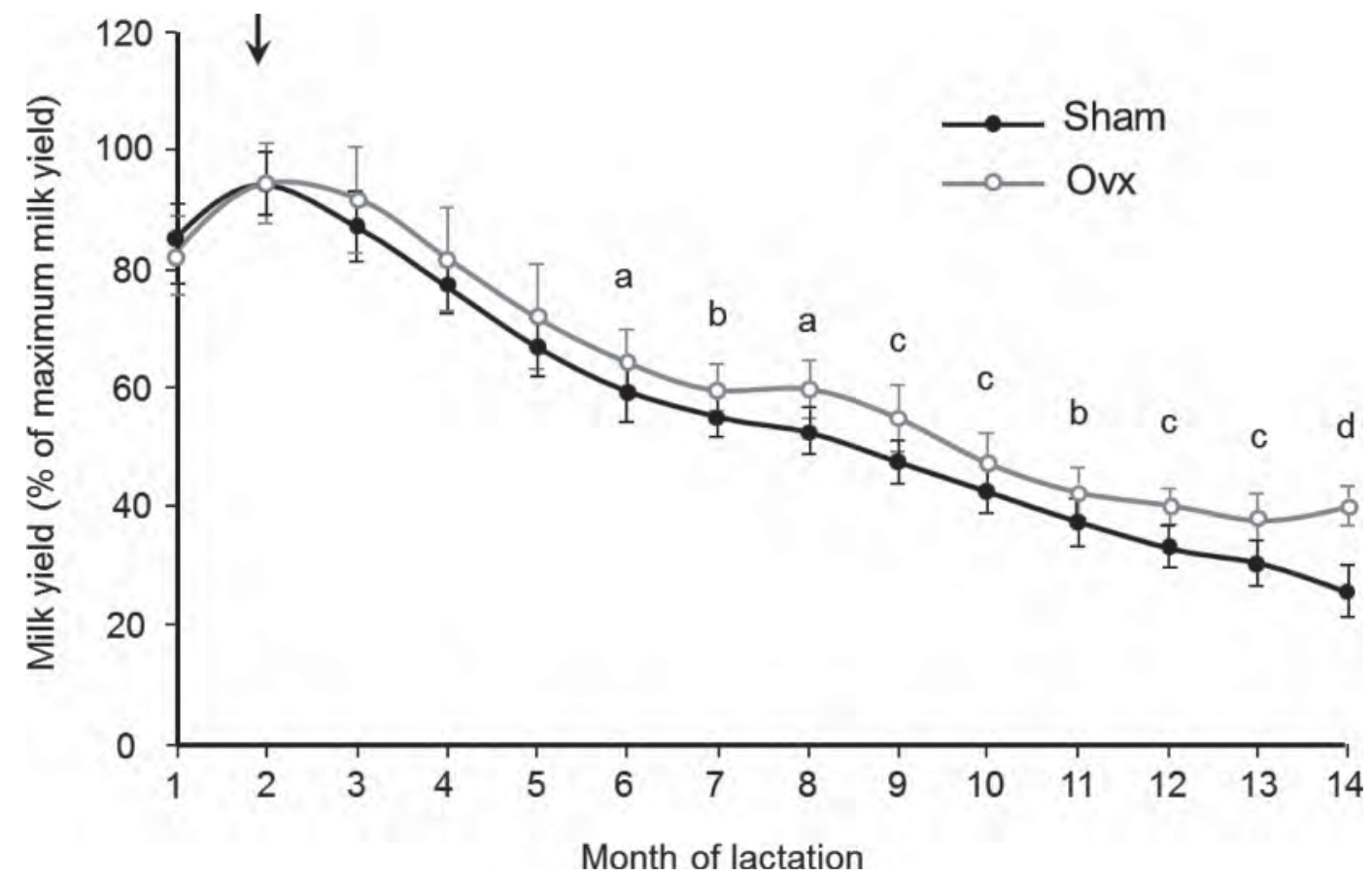

Figure 2. Effect of the ovariectomy on the milk yield during 14 mo of lactation. Multiparous nonpregnant cows were ovariectomized (Ovx, $\mathrm{n}=4$ ) or sham-operated (sham, $\mathrm{n}=5$ ) at 2 mo of lactation and were slaughtered after 14 mo of lactation. The daily milk yield was recorded during the 14 mo and expressed as means \pm SEM of the percentage of the maximum milk yield. The arrow indicates the time of surgery. Note that ovariectomy improved milk yield from 5 to 14 mo of lactation. The effect was considered significant at ${ }^{\mathrm{b}} P<0.05,{ }^{\mathrm{c}} P<0.01$, and ${ }^{\mathrm{d}} P<0.001$, and it tended to be significant at ${ }^{\mathrm{a}} P<0.1$. 

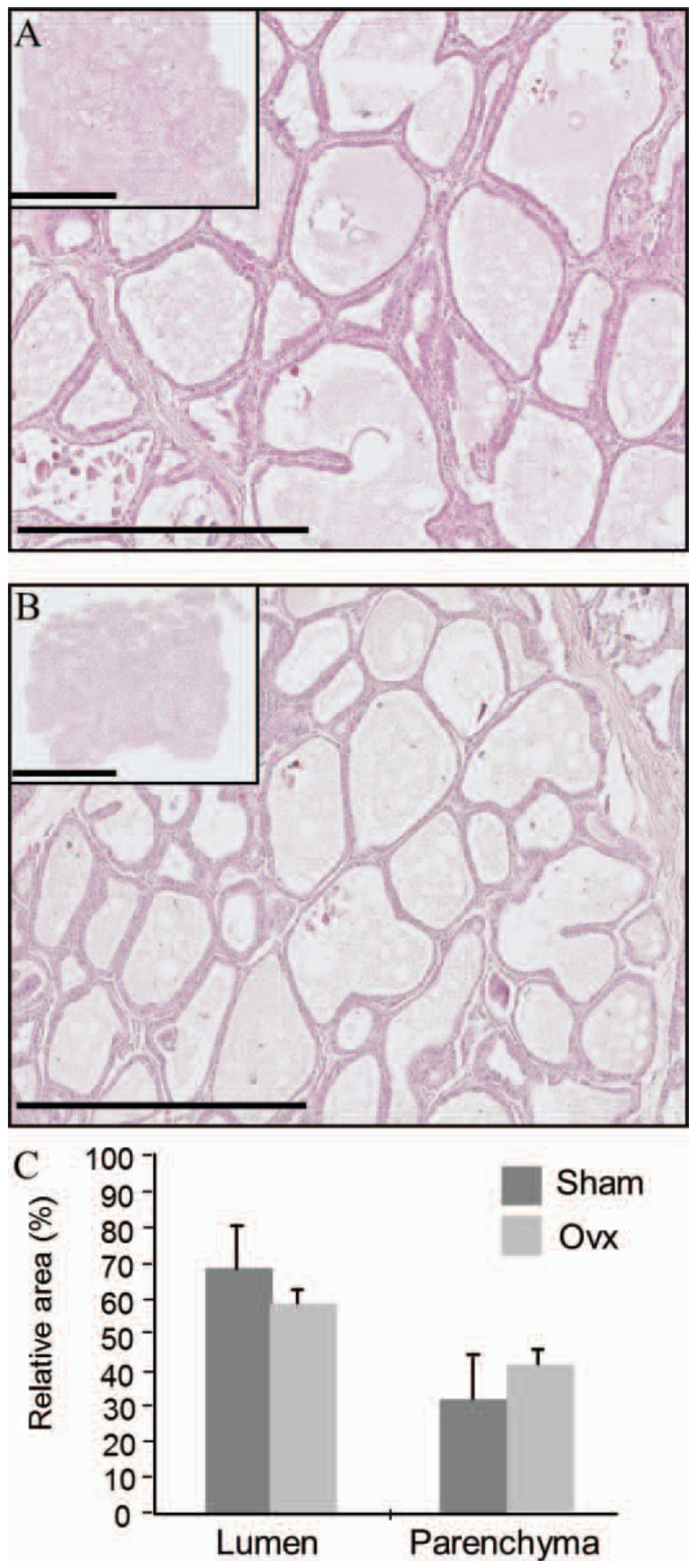

Figure 3. Effect of the ovariectomy on the morphology of mammary tissue after 14 mo of lactation. Multiparous nonpregnant cows were ovariectomized (Ovx, $\mathrm{n}=4$ ) or sham-operated (sham, $\mathrm{n}=5$ ) at 2 mo of lactation and slaughtered after 14 mo of lactation. Histological staining with hematoxylin and eosin was performed on paraffin-embedded mammary tissue sections for sham (A) and Ovx (B) cows. Note the presence of a well-developed secretory tissue, which has a thin epithelium, a large lumen area, and ducts, in both the Sham and the Ovx cows. Bars represent $4 \mathrm{~mm}$ and $500 \mu \mathrm{m}$ for the low and high magnifications, respectively. (C) Lumen area and mammary parenchyma area are expressed as percentages (mean \pm SEM) relative to the total mammary tissue section area. Note that the quantitative image analysis revealed no statistical difference in lumen and parenchyma areas. Color version available in the online PDF. of the mammary gland to progesterone and estrogen, thereby improving lactation persistency (Bertilsson et al., 1997). Bachman et al. (1988) noted that the decrease in MY started in the third month of pregnancy, which coincides with the onset of estrogen secretion by the fetoplacental unit (Patel et al., 1999). This finding suggests that estrogen, rather than progesterone, plays a primary role in MY decline. Moreover, in a lactating udder, estrogen appears to accelerate involution of the mammary gland because estrogen administration in mid or late lactation cows induced a decrease in MY and an increase in total milk protein content (Athie et al., 1996; Delbecchi et al., 2005). Specifically, an exogenous estrogen treatment increased both stanniocalcin (Delbecchi et al., 2005) and lactoferrin concentrations (Athie et al., 1996) and decreased $\alpha$-lactalbumin (Athie et al., 1996) concentrations in milk. Delbecchi and Lacasse (2006) investigated the effect of the suppression of ovarian secretion on lactation persistency. These researchers used implants of deslorelin, which is a GnRH agonist, to suppress the ovarian cyclicity. Despite the rapid decreases in estrogen and progesterone plasma concentrations that occurred following insertion of the implant, the authors of that study did not observe any modification in MY within 6 mo after starting the treatment (Delbecchi and Lacasse, 2006). In the studies previously mentioned (Mollett et al., 1976; Athie et al., 1996; Delbecchi et al., 2005), in which estrogen negatively affected MY, the animals were subjected to supraphysiological doses of steroid hormones. Thus, the short-term effect on MY observed in these studies could, in part, be the result of the high estrogen concentrations. Similar to the Delbecchi and Lacasse (2006) study, the animals in our study were subjected to small variations in hormonal levels. In this study, we found that ovariectomy only affected MY 4 mo after surgery. Taken together, these results suggest that at low concentrations, ovarian steroids have a long-term effect on the MY. Although estrogen and progesterone are believed to be the primary ovarian factors involved in the modulation of lactation persistency, it is interesting to note that in our study we removed the ovaries, whereas Delbecchi and Lacasse (2006) suppressed secretion of ovarian steroids by acting on the central control of ovarian cyclicity. It is known that the ovaries produce numerous hormones (Driancourt, 2001), and surgical removal of the ovaries could affect other pathways that contribute to modulate lactation persistency.

The mammary gland undergoes numerous changes during lactation, and mammary tissue needs to be remodeled to allow variations in secretory cell number, alveolar size, and ductal growth (Stefanon et al., 2002). Matrix metalloproteinases play a predominant role during mammary gland involution, during mammogenesis 


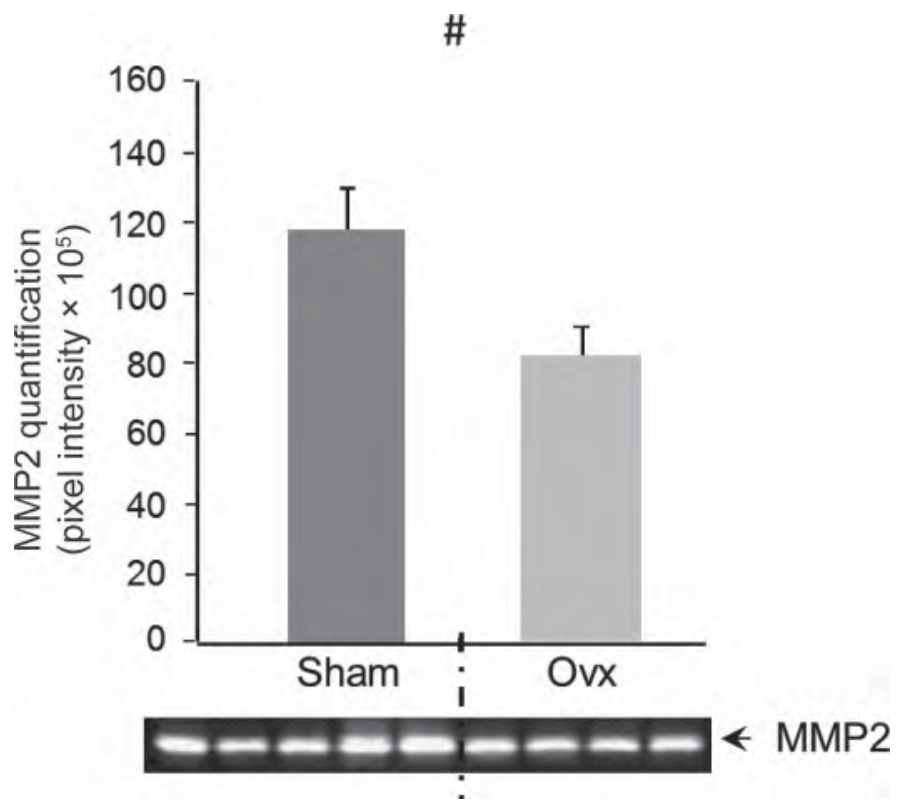

Figure 4. Effect of the ovariectomy on mammary gland remodeling after 14 mo of lactation, as illustrated by matrix metalloproteinase 2 (MMP2) activity in milk. Multiparous nonpregnant cows were ovariectomized (Ovx, $\mathrm{n}=4)$ or sham-operated (sham, $\mathrm{n}=5$ ) at 2 mo of lactation and slaughtered after 14 mo of lactation. Mammary gland remodeling at slaughter was assessed in both the sham and Ovx cows by measuring the MMP2 activity in milk via gelatin zymography. A zymography band corresponding to the MMP2 gelatinase activity was detected at $57 \mathrm{kDa}$. Each band corresponds to one cow. The pixel intensity is expressed as means \pm SEM. Note that the ovariectomy tended to decrease activity of MMP2 $(\# P<0.1)$.

at puberty, and during pregnancy. Mammary tissue remodeling by MMP can also occur during lactation and can influence apoptosis of MEC (Pullan et al., 1996). Additionally, Ambili et al. (1998) demonstrated that certain MMP could be positively regulated by estrogen during involution of the rat mammary gland. Although we did not observe any differences in mammary gland weights and mammary tissue morphology between the 2 groups, it appeared that ovariectomy tended to reduce MMP activity and decreased MEC apoptosis. Consequently, we can hypothesize that removal of the main source of ovarian steroids would limit MMP activation and preserve the integrity of the extracellular matrix, thereby reducing the rate of MEC apoptosis and improving lactation persistency. Indeed, the decline in MY after the peak of lactation could primarily result from a loss of secretory cells by apoptosis (Stefanon et al., 2002). Thus, modulation of lactation persistency by livestock management factors requires modification of the proliferation-apoptosis balance via modulation of pro-apoptotic and survival signals.

Milking frequency, reproduction plan, and feeding levels are known to influence the persistency of lactation (Capuco et al., 2003). These factors limit or accel- erate the decline in MY after the peak of lactation by regulating the proliferation-apoptosis balance and tissue remodeling in the mammary gland (Stefanon et al., 2002). In future studies, we will focus on the identification of ovarian factors and the cellular and molecular mechanisms involved in the improvement of lactation persistency in ovariectomized cows. Mammary tissue changes that occur during lactation can be assessed by quantifying the expression of proteins involved in several apoptotic pathways or proliferative mechanisms at both the transcriptional and transductional levels.

\section{CONCLUSIONS}

We demonstrated that ovariectomy of lactating cows improved lactation persistency by limiting the decrease in MY after the peak of lactation without modifying the milk composition. Moreover, ovariectomy limited the decrease in MY over time in correspondence with reduced mammary tissue remodeling (MMP activity) and less apparent apoptosis of MEC. Taken together, these results indicate that removal of ovarian secretions would delay involution of the mammary gland.

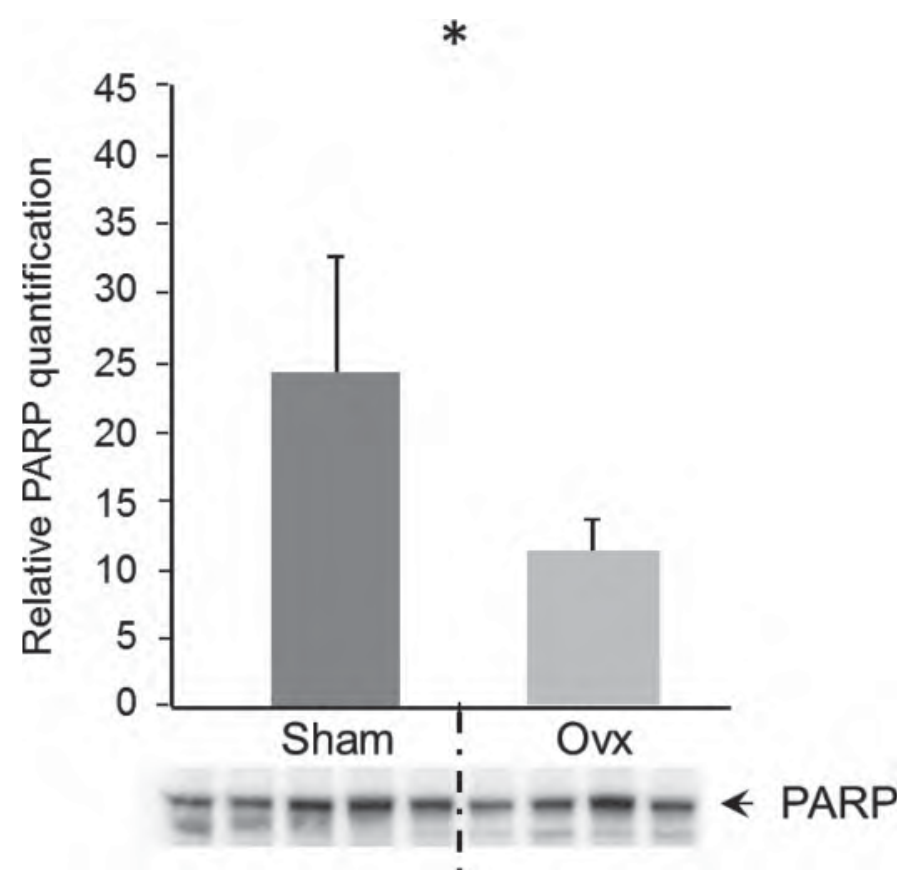

Figure 5. Effect of the ovariectomy on mammary epithelial cell apoptosis after 14 mo of lactation. Multiparous nonpregnant cows were ovariectomized (Ovx, $\mathrm{n}=4$ ) or sham-operated (sham, $\mathrm{n}=5$ ) at $2 \mathrm{mo}$ of lactation and slaughtered after 14 mo of lactation. Apoptosis in the mammary gland was assessed by Western blot quantification of the poly(ADP-ribose) polymerase (PARP) protein level, which was normalized by the actin level. The PARP protein level at slaughter is expressed as a ratio relative to the PARP protein expression at $2 \mathrm{mo}$ of lactation, which was before the ovariectomy. The relative quantification of PARP is expressed as means \pm SEM. Note that the ovariectomy decreased the PARP protein level at slaughter $\left({ }^{*} P<0.05\right)$. 


\section{ACKNOWLEDGMENTS}

The authors are grateful to the staff of the INRA's experimental farm in Le Pin-au-Haras (France), especially Yves Gallard, for providing animals and installations, and to Maxime Jacquet and Laurent Vandenbrouck for their care of the experimental animals and assistance with the measurements throughout the study. Thanks are also due to Luc Delaby (INRA Rennes) for providing assistance with statistical analyses, to Sandra Wiart (INRA Rennes) and Alain Fautrel from the H2P2 laboratory for assisting with the histological analysis, and to American Journal Experts (Durham, NC) for the language editing. This research was co-supported by the French National Institute of Agricultural Science (INRA), the PhASE department (Tours, France), and the GALA association (Janzé, France).

\section{REFERENCES}

Akers, R. M., W. E. Beal, T. B. McFadden, and A. V. Capuco. 1990. Morphometric analysis of involuting bovine mammary tissue after 21 or 42 days on non-suckling. J. Anim. Sci. 68:3604-3613.

Akers, R. M., S. Ellis, and S. Berry. 2005. Ovarian and IGF-I axis control of mammary development in prepubertal heifers. Domest. Anim. Endocrinol. 29:259-267.

Ambili, M., K. Jayasree, and P. Sudhakaran. 1998. 60K gelatinase involved in mammary gland involution is regulated by beta-oestradiol. Biochim. Biophys. Acta 1403:219-231.

Athie, F., K. Bachman, H. Head, M. Hayen, and C. Wilcox. 1996. Estrogen administered at final milk removal accelerates involution of bovine mammary gland. J. Dairy Sci. 79:220-226.

Bachman, K. C., M. Hayen, D. Morse, and C. Wilcox. 1988. Effect of pregnancy, milk yield, and somatic cell count on bovine milk fat hydrolysis. J. Dairy Sci. 71:925-931.

Berry, S. D., P. Jobst, S. Ellis, R. Howard, A. Capuco, and R. Akers. 2003. Mammary epithelial proliferation and estrogen receptor alpha expression in prepubertal heifers: Effects of ovariectomy and growth hormone. J. Dairy Sci. 86:2098-2105.

Bertilsson, J., B. Berglund, G. Ratnayake, K. Svennersten Sjaunja, and H. Wiktorsson. 1997. Optimising lactation cycles for the highyielding dairy cow. A European perspective. Livest. Prod. Sci. 50:5-13.

Boulares, A. H., A. G. Yakovlev, V. Ivanova, B. A. Stoica, G. Wang, S. Iyer, and M. Smulson. 1999. Role of poly(ADP-ribose) polymerase (PARP) cleavage in apoptosis. J. Biol. Chem. 274:22932-22940.

Boutinaud, M., J. Guinard-Flament, and H. Jammes. 2004. The number and activity of mammary epithelial cells, determining factors for milk production. Reprod. Nutr. Dev. 44:499-508.

Capuco, A. V., S. Ellis, S. Hale, E. Long, R. Erdman, X. Zhao, and M. Paape. 2003. Lactation persistency: Insights from mammary cell proliferation studies. J. Anim. Sci. 81:18-31.

Chappat, P. 1993. La castration de la vache. Bulletin des GTV 1:5363.

Delbecchi, L., and P. Lacasse. 2006. Suppression of estrous cycles in lactating cows has no effect on milk production. J. Dairy Sci. 89:636-639.

Delbecchi, L., N. Miller, C. Prud'homme, D. Petitclerc, G. Wagner, and P. Lacasse. 2005. 17beta-Estradiol reduces milk synthesis and increases stanniocalcin gene expression in the mammary gland of lactating cows. Livest. Prod. Sci. 98:57-66.
Dessauge, F., L. Finot, S. Wiart, J. Aubry, and S. Ellis. 2009. Effects of ovariectomy in prepubertal goats. J. Physiol. Pharmacol. 60(Suppl. 3):127-133.

Driancourt, M. A. 2001. Regulation of ovarian follicular dynamics in farm animals. Implications for manipulation of reproduction. Theriogenology 55:1211-1239.

du Roizel-Marlier, T. 2004. Effets de l'ovariectomie sur la production laitière des vaches de races Montbéliarde et Prim'Holstein. Etude cas-témoins. DMV Thesis. Nat. Vet. Sch. Alfort, Maisons-Alfort, France.

Farr, V. C., K. Stelwagen, L. Cate, A. Molenaar, T. McFadden, and S. Davis. 1996. An improved method for the routine biopsy of bovine mammary tissue. J. Dairy Sci. 79:543-549.

Guenette, R. S., H. B. Corbeil, J. Léger, K. Wong, V. Mézl, M. Mooibroek, and M. Tenniswood. 1994. Induction of gene expression during involution of the mammary gland of the rat. J. Mol. Endocrinol. 12:47-60.

Hojsgaard, S., U. Halekoh, and J. Yan. 2006. The R package geepack for generalized estimating equations. J. Stat. Softw. 15:1-11.

Johnson, M. L., D. A. Redmer, and L. P. Reynolds. 1997. Effects of ovarian steroids on uterine growth, morphology, and cell proliferation in ovariectomized, steroid-treated ewes. Biol. Reprod. $57: 588-596$

Miller, N., L. Delbecchi, D. Petitclerc, G. F. Wagner, B. G. Talbot, and P. Lacasse. 2006. Effect of stage of lactation and parity on mammary gland cell renewal. J. Dairy Sci. 89:4669-4677.

Mollett, T., R. Erb, E. Monk, and P. Malven. 1976. Changes in estrogen, progesterone, prolactine and lactation traits associated with injection of estradiol-17beta and progesterone into lactating cows. J. Dairy Sci. 42:655-663.

Norgaard, J., M. Sorensen, P. Theil, J. Sehested, and K. Sejrsen. 2008 Effect of pregnancy and feeding level on cell turnover and expression of related genes in the mammary tissue of lactating dairy cows. Animal 2:588-594.

Patel, O. V., N. Takenouchi, T. Takahashi, M. Hirako, N. Sasaki, and I. Domeki. 1999. Plasma oestrone and oestradiol concentrations throughout gestation in cattle: Relationship to stage of gestation and fetal number. Res. Vet. Sci. 66:129-133.

Pullan, S., J. Wilson, A. Metcalfe, G. M. Edwards, N. Goberdhan, J. Tilly, J. A. Hickman, C. Dive, and C. H. Streuli. 1996. Requirement of basement membrane for the suppression of programmed cell death in mammary epithelium. J. Cell Sci. 109:631-642.

Purup, S., K. Sejrsen, and R. M. Akers. 1995. Effect of bovine GH and ovariectomy on mammary tissue sensitivity to IGF-I in prepubertal heifers. J. Endocrinol. 144:153-158.

Rabot, A., F. Sinowatz, B. Berisha, H. H. D. Meyer, and D. Schams. 2007. Expression and localization of extracellular matrix-degrading proteinases and their inhibitors in the bovine mammary gland during development, function, and involution. J. Dairy Sci. 90:740-748.

Schutz, M. M., L. B. Hansen, G. R. Steuernagel, and A. L. Kuck. 1990. Variation of milk, fat, protein, and somatic cells for dairy cattle. J. Dairy Sci. 73:484-493.

Sölkner, J., and W. Fuchs. 1987. A comparison of different measures of persistency with special respect to variation of test-day milk yields. Livest. Prod. Sci. 16:305-319.

Stefanon, B., M. Colitti, G. Gabai, C. Knight, and C. Wilde. 2002. Mammary apoptosis and lactation persistency in dairy animals. J. Dairy Res. 69:37-52.

Turner, C. W., H. Yamamoto, and H. L. Ruppert. 1956. The experimental induction of growth of the cow's udder and the initiation of milk secretion. J. Dairy Sci. 39:1717-1729.

Wallace, C. 1953. Observations on mammary development in calves and lambs. J. Agric. Sci. 43:413-421. 